\title{
Deficit Irrigation Affects Growth, Yield, Vitamin C Content, and Irrigation Water Use Efficiency of Hot Pepper Grown in Soilless Culture
}

\author{
Adel F. Ahmed ${ }^{1}$, Hongjun $\mathbf{Y u}^{1}$, Xueyong Yang, and Weijie Jiang ${ }^{2}$ \\ Institute of Vegetables and Flowers, Chinese Academy of Agricultural \\ Sciences, No.12 Zhongguancun South Street, Haidian District, Beijing \\ 100081, China
}

Additional index words. hot pepper, irrigation deficiency, saving water, vitamin C

\begin{abstract}
Hot pepper (Capsicum annuum cv. Battle) was grown in a 1:1 v/v sand-to-cotton stalk compost and subjected to four irrigation treatments: $100 \%$ of water-holding capacity (control) and $85 \%, 70 \%$, and $55 \%$ of water-holding capacity, which were considered deficit irrigation treatments. All treatments were given to the plants at the first day of transplanting and continued during the whole growing season. Our results demonstrated that deficit irrigation had a negative effect on plant growth and yield. Increasing irrigation deficiency exhibited a reduction in vegetative growth, fruit parameters, and yield and a nonsignificant increase in irrigation water use efficiency and a corresponding reduction in the amount of irrigation water. Vitamin $C$ content in fruit was significantly decreased by deficit irrigation treatments at various ripening stages. Water-holding capacity of $100 \%$ and $85 \%$, respectively, resulted in the highest content of vitamin $C$ obtained at the ripening stage. We concluded that 'Battle' hot pepper is sensitive to deficit irrigation. Supplying this cultivar with water at $85 \%$ of water-holding capacity could be a practical irrigation technique for high value of vitamin $C$ production as well as saving a large amount of water, which outweighs the decrease in total fresh yield of fruit, especially in areas suffering from water shortage.
\end{abstract}

Available water for agriculture is becoming limited all over the world, and there is an urgent necessity to adopt effective strategies of irrigation management. Deficit irrigation is a strategy that allows a crop to tolerate some degree of water deficit to reduce costs and potentially increase income. It can lead to increased net income where water costs are high or where water supplies are limited (English and Raja, 1996).

Hot pepper (Capsicum annuum) is a crop of major economic importance and is commercially cultivated in China, Korea, East Indies, the United States, and many other countries. Its cultivation is confined to warm and semiarid countries where water is often a limiting factor for production, which makes the optimization of water management necessary. Pepper is among the most sensitive horticultural plants to deficit irrigation because of the wide range of transpiring leaf

Received for publication 3 Mar. 2014. Accepted for publication 31 Mar. 2014.

This work was supported by the earmarked fund for the China Agricultural Research System (CARS-25-C-09), the Science-Tech of Agri-industry Project (201203095, 201203001) of the Ministry of Agriculture, P.R. China. and the national key project (2011BAD12B01) of the Ministry of Sciences and Technology, P.R. China.

${ }^{1}$ These authors contributed equally to this work.

${ }^{2}$ To whom reprint requests should be addressed; e-mail jiangweijie@caas.cn. surface, high stomatal conductance (Alvino et al., 1994), and its shallow root system (Dimitrov and Ovtcharrova, 1995). Pepper fruits are a rich source of antioxidant compounds (Howard et al., 2000; Marín et al., 2004; Palevitch and Craker, 1995). Dietary antioxidants are beneficial because of their protective roles against multiple diseases such as cancer, anemia, diabetes, and cardiovascular diseases, and it is becoming increasingly important for growers who want to satisfy the demand of consumers for products with a high content of healthpromoting constituents. Vitamin $\mathrm{C}$ is an important antioxidant compound of pepper fruits, chelating heavy metal ions (Namiki, 1990), reducing the risk of arteriosclerosis, cardiovascular diseases, and some forms of cancer (Harris, 1996).

The effect of deficit irrigation on hot pepper growth and yield is controversial. Although negative effects of deficit irrigation on pepper fruit yield have been reported by several investigators such as Abayomi et al. (2012), Dagdelen et al. (2004), Dorji et al. (2005), Ferrara et al. (2011), Gencoglan et al. (2006), Ismail (2010), Kirda et al. (2007), and Kulkarni and Phalke (2009), others found that fruit dry mass was increased (Chartzoulakis and Drosos, 1997) or unaffected by water stress (Ruiz-Lau et al., 2011). This was accompanied by a decrease in plant height, root dry weight, and root/ shoot relation compared with those plants irrigated daily.
Although increasing water use efficiency by decreasing water application was proposed unattainable by Abebe (2009) because yield reduction is remarkably higher as a result of decreased water supply, Ismail (2010) found that giving $85 \%$ and $70 \%$ of the field capacity saved $41 \%$ and $85 \%$, respectively, of the irrigation water.

Several investigators have reported a negative effect of water stress on fruit content of vitamin $\mathrm{C}$ such as Mahendran and Bandara (2000) on chili cultivar Arunalu and Vijitha and Mahendran (2010) on tomato. On the contrary, vitamin C content showed a $23 \%$ increase when peppers were less watered compared with high-irrigated fruit (Marín et al., 2009). An increase in vitamin $\mathrm{C}$ content with moderate water deficits was demonstrated by Toivonen et al. (1994) on broccoli and the same results observed in leeks grown under low irrigation frequency (Sorensen et al., 1995). Maturity stage also affects vitamin C content. Marín et al. (2009) found that green peppers grown under low irrigation frequency had similar content of vitamin $\mathrm{C}$ to red fruits and only the highly irrigated green fruits showed lower content of vitamin $\mathrm{C}$ with respect to red fruits. Navarro et al. (2006) found that red peppers had more vitamin $\mathrm{C}$ content than green ones. Other authors have found that vitamin $\mathrm{C}$ increased or remained constant as pepper fruits matured (Howard et al., 1994, 2000; Osuna-Garcia et al., 1998) and declined with further ripening (Gnayfeed et al., 2001).

Thus, because of varied effects of deficit irrigation on fruit, yield, and vitamin $\mathrm{C}$ content in hot pepper, this study was conducted to evaluate the effects of deficit irrigation on morphological and fruit parameters, growth, and yield of 'Battle' hot pepper as well as vitamin $\mathrm{C}$ content at different ripening stages. We aimed also at determining the critical deficit irrigation level for good growth, fruit yield, and high vitamin $\mathrm{C}$ content of this cultivar to save a high amount of water irrigation.

\section{Materials and Methods}

A greenhouse experiment was conducted at the Soilless Culture Department, Vegetables and Flowers Institute, Chinese Academy of Agricultural Sciences, Beijing, China from May to Aug. 2012. During the growing season, the average temperature and relative humidity were $26.3^{\circ} \mathrm{C}$ and $67.8 \%$, respectively.

\section{Growth medium and plant materials}

A sand-to-cotton stalk compost $(1: 1 \mathrm{v} / \mathrm{v})$ was used as a growth medium; $7 \mathrm{~L}$ were used per pot. The physical and chemical properties of the growth medium used in this study are presented in Table 1. The seedlings of hot pepper (Capsicum annuum cv. Battle) were transplanted at the eight-leaf stage, one plant per pot.

\section{Fertilization}

A mixture of organic and inorganic fertilizers, containing nitrogen, phosphorus, and 
potassium $25 \%$ or greater, organic $25 \%$ or greater, water $20 \%$ or greater, and the effective number of living bacteria 0.2 hundred million per gram or greater was used. Before transplanting, the fertilizer was mixed with the growth medium at $10 \mathrm{~kg} \cdot \mathrm{m}^{-3}$. After transplanting, a dosage of $10 \mathrm{~g}$ fertilizer per pot was added three times at 20,40, and $60 \mathrm{~d}$ after transplanting.

\section{Irrigation treatments and experimental design}

The maximum amount of water can held by soil or medium is known as water-holding capacity (WHC). Water-holding capacity of medium was calculated from the following equation: water-holding capacity $(\%)=[$ total porosity $(\%)$ - air space (\%)]. Four irrigation treatments, $100 \%, 85 \%, 70 \%$, and $55 \%$, of WHC were used during the whole growing season, which will be referred to in the text as $\mathrm{T} 1, \mathrm{~T} 2, \mathrm{~T} 3$, and $\mathrm{T} 4$, respectively. A full irrigation treatment (T1) was considered as a control. The second, third, and the fourth treatments (T2, T3, and T4) were considered as deficit irrigation treatments. All water treatments were given to the plants on the same day of transplanting. The desired moisture contents of pots were daily monitored by HH2 moisture meter Version 4.0 (Delta-T Devices Ltd., U.K.) and maintained through water application, if required. The experiment was organized in a completely randomized design with three replications per treatment; each replication had seven plants (21 plants per treatment).

\section{Measurements}

Morphological characteristics. At the end of the experiment, three plants were randomly selected from each treatment replication to measure some morphological parameters per plant as follows:

Plant height $(\mathrm{cm})$ was measured by a ruler from the soil surface of the pot to the top of the plant. The number of branches was counted by the naked eye. Stem diameter (cm) was measured by calipers (soil surface).
Leaf area $\left(\mathrm{cm}^{2}\right)$ was measured by an Area meter (AM 300 Bio Scientific Ltd., U.K.). Fresh weight of shoots $(\mathrm{g})$ was weighted with digital balance. Dry weight of shoots $(\mathrm{g})$ samples were dried at $60{ }^{\circ} \mathrm{C}$ until a constant weight and then weighted by the same balance. Days to flower set were calculated as the number of days from transplanting to flower set. Days to first harvest were calculated as the number of days from transplanting to first fruit maturity.

The root system was carefully removed from the pot to obtain the complete root. After several washes in water, root length $(\mathrm{cm})$, fresh weight of roots $(\mathrm{g}) / \mathrm{plant}$, dry weight of roots $(\mathrm{g}) /$ plant, and root-to-shoot ratio were determined. Dry weight of roots (g)/plant was obtained after the samples were dried at $60{ }^{\circ} \mathrm{C}$ until they had a constant weight. Root-to-shoot ratio was calculated by dividing fresh weight of roots by the fresh weight of shoots.

\section{Harvesting}

Fruits were harvested at three periods during the season. The early period of harvesting started $48 \mathrm{~d}$ after transplanting (which is $30 \mathrm{~d}$ after flowering). The middle and late periods of harvesting started after 11 and $30 \mathrm{~d}$ of the first harvest, respectively. During these harvesting periods, the following characteristics were measured: number of fruits was quantified from three randomly selected plants from each treatment replication. During each harvesting period, 10 fruits were randomly selected to calculate the average of fruit length $(\mathrm{cm})$, fruit diameter $(\mathrm{cm})$, and fruit weight $(\mathrm{g})$. Fruit yield $(\mathrm{g}) /$ plant was calculated from the number of fruits per plant multiplied by fruit weights per plant. Total fruit yield (g)/plant is a collection of fruit yield per plant in all three periods of harvesting. Yield reduction (\%) was calculated from the following equation: yield reduction $(\%)=[$ (yield of control yield of treatment)/yield of control]*100.

Irrigation water use efficiency was calculated according to Guang-Cheng et al. (2008) by dividing the total fresh weight of fruit $(\mathrm{g})$ by the volume of irrigation water (L) applied to the plant of each treatment during the whole season.

Water saving (\%) was calculated from the following equation: water saving $(\%)=$ [(water consumption of control - water consumption of treatment)/water consumption of control]*100.

\section{Vitamin $C$ content}

Fresh fruits were sampled at 10, 20, 30, 40,50 , and $60 \mathrm{~d}$ after flowering for all treatments. The fruits were washed thoroughly in water. The juices were extracted after cutting the whole fruit to small pieces and $100 \mathrm{~g}$ of these pieces were mixed with $100 \mathrm{~mL}$ of oxalic acid $2 \%$, then $10 \mathrm{~g}$ of this mixture was used to determine vitamin $\mathrm{C}$ content by using standard methods of analysis (AOAC, 1998).

\section{Statistical analysis}

Data were statistically analyzed using Statistix Version 8.1 software. Differences between means were determined using the least significant difference test at $P<0.05$. The analyzed data were then presented as mean \pm SD of the mean.

\section{Results}

Morphological characteristics. Data presented in Table 2 demonstrate that morphological characteristics of pepper plants were affected by deficit irrigation. In our study, restricting the water supply caused a significant decrease in plant height, stem diameter, number of branches, leaf area, and fresh and dry weights of shoots. T4 and T3 treatments, respectively, resulted in the maximum reduction relative to the control. The highest reduction in plant height was $35.09 \%$ and $19.65 \%$, whereas the highest reduction in stem diameter was $8.69 \%$ and $5.43 \%$. Meanwhile, the maximum reduction in number of branches was $26.18 \%$ and $23.82 \%$. The greatest reduction in leaf area for these treatments

Table 1. Physical and chemical properties of growth medium.

\begin{tabular}{|c|c|c|c|c|c|c|c|c|c|c|}
\hline \multirow[b]{2}{*}{ Properties } & \multicolumn{5}{|c|}{ Physical properties } & \multicolumn{5}{|c|}{ Chemical properties } \\
\hline & $\overline{\mathrm{BD}\left(\mathrm{g} \cdot \mathrm{cm}^{-3}\right)}$ & AS (\%) & WHC (\%) & ТР (\%) & $\mathrm{EC}\left(\mathrm{mS} \cdot \mathrm{cm}^{-1}\right)$ & $\mathrm{pH}$ & TOC $\left(\mathrm{g} \cdot \mathrm{kg}^{-1}\right)$ & $\mathrm{TN}\left(\mathrm{g} \cdot \mathrm{kg}^{-1}\right)$ & $\mathrm{OM}\left(\mathrm{g} \cdot \mathrm{kg}^{-1}\right)$ & $\mathrm{C} / \mathrm{N}$ ratic \\
\hline
\end{tabular}

$\mathrm{BD}=$ bulk density; $\mathrm{AS}=$ air space $; \mathrm{WHC}=$ water-holding capacity; $\mathrm{TP}=$ total porosity; $\mathrm{EC}=$ electrical conductivity; $\mathrm{TOC}=$ total organic carbon; $\mathrm{TN}=$ total nitrogen; $\mathrm{OM}=$ organic matter; $\mathrm{C} / \mathrm{N}=$ carbon-to-nitrogen ratio.

Table 2. Effect of deficit irrigation on certain morphological characteristics of hot pepper plant.

\begin{tabular}{|c|c|c|c|c|c|c|}
\hline WHC $(\%)^{z}$ & Plant ht $(\mathrm{cm})$ & Stem diam $(\mathrm{cm})$ & Number of branches & Leaf area $\left(\mathrm{cm}^{2}\right)$ & Fresh wt shoots (g) & Dry wt shoots $(\mathrm{g})$ \\
\hline$\overline{\mathrm{T}} 1^{\mathrm{y}}$ & $93.63 \pm 3.23^{\mathrm{u}} \mathrm{a}^{\mathrm{t}}$ & $0.92 \pm 0.03 \mathrm{a}$ & $4.66 \pm 0.34 \mathrm{a}$ & $14.19 \pm 0.06 \mathrm{a}$ & $201.12 \pm 6.70 \mathrm{a}$ & $72.51 \pm 0.49 \mathrm{a}$ \\
\hline $\mathrm{T} 2^{\mathrm{x}}$ & $86.42 \pm 2.22 b$ & $0.88 \pm 0.01 \mathrm{~b}$ & $4.33 \pm 0.33 \mathrm{a}$ & $13.76 \pm 0.07 b$ & $170.06 \pm 9.50 \mathrm{~b}$ & $63.34 \pm 1.20 \mathrm{~b}$ \\
\hline $\mathrm{T} 3^{\mathrm{w}}$ & $75.23 \pm 1.65 \mathrm{c}$ & $0.87 \pm 0.01 \mathrm{bc}$ & $3.55 \pm 0.19 \mathrm{~b}$ & $13.17 \pm 0.03 \mathrm{c}$ & $150.56 \pm 4.50 \mathrm{c}$ & $56.08 \pm 0.73 \mathrm{c}$ \\
\hline $\mathrm{T} 4^{\mathrm{v}}$ & $60.77 \pm 1.38 \mathrm{~d}$ & $0.84 \pm 0.02 \mathrm{c}$ & $3.44 \pm 0.38 \mathrm{~b}$ & $12.20 \pm 0.02 \mathrm{~d}$ & $108.37 \pm 6.44 \mathrm{~d}$ & $42.21 \pm 0.53 \mathrm{~d}$ \\
\hline
\end{tabular}

${ }^{\mathrm{z}}$ Water-holding capacity.

y One hundred percent of water-holding capacity (control).

${ }^{x}$ Eighty-five percent of water-holding capacity.

wSeventy percent of water-holding capacity.

${ }^{\mathrm{v}}$ Fifty-five percent of water-holding capacity.

uData are mean \pm SD $(n=3)$.

'Values followed by the same letters within a column are not significantly different $(P<0.05)$ according to the least significant difference test. 
was $14.02 \%$ and $7.74 \%$, respectively. Furthermore, the highest reduction in fresh weight of shoots was $46.11 \%$ and $25.14 \%$, whereas the highest reduction in dry weight of shoots was $41.78 \%$ and $22.65 \%$, respectively.

Days to flower set and first harvesting. Data illustrated in Figure 1 reveal that deficit irrigation caused a significant acceleration in the time of flower set and first harvesting of hot pepper. The highest acceleration in the time of flower set was $18.75 \%$ followed by $14.06 \%$ and $4.68 \%$. Meanwhile, the maximum acceleration in the time of first harvesting was $9.31 \%$ followed by $6.22 \%$ and $2.49 \%$ for T4, T3, and T2, respectively, as compared with the control.

Fruit parameters during periods of harvesting. The averages of fruit parameters including number, length, diameter, and weight of fruit for all irrigation treatments during periods of harvesting are shown in Table 3. Fruit number was significantly decreased by deficit irrigation during the early and middle periods of harvesting. However, during the late harvesting period, differences in fruit number were nonsignificant. During periods of harvesting, the highest fruit number was obtained from the $\mathrm{T} 1$ treatment followed by $\mathrm{T} 2$, T3, and T4, respectively, whereas increased deficit irrigation caused a significant reduction in fruit length where T1 gave the highest fruit length followed by $\mathrm{T} 2, \mathrm{~T} 3$, and T4, respectively.

Fruit diameter and weight exhibited similar trends to fruit length as demonstrated in Table 3. Decreasing water supply caused a significant decrease in diameter and weight of fruit during periods of harvesting. The highest fruit diameter and weight were obtained from $\mathrm{T} 1$ followed by $\mathrm{T} 2, \mathrm{~T} 3$, and $\mathrm{T} 4$ in descending order.

Fresh fruit yield and total yield. Data presented in Table 4 reveal that the highest fresh fruit yield per plant was obtained from the early period of harvesting followed by middle and late periods, respectively. Fresh fruit yield per plant during periods of harvesting and total yield were strongly affected by deficit irrigation.

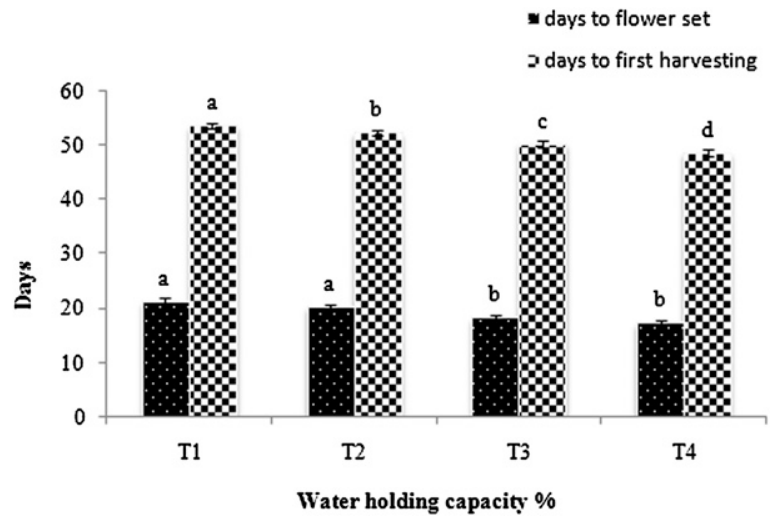

Fig. 1. Effect of deficit irrigation on days to flower set and first harvesting of pepper plant. $\mathrm{T} 1=100 \%$ of waterholding capacity (control); $\mathrm{T} 2=85 \%$ of water-holding capacity; T3 $=70 \%$ of water-holding capacity; T4 $=55 \%$ of water-holding capacity. Vertical bars denote the SD. Columns in figure that are headed with the same letter are not significantly different $(P<0.05)$ according to the least significant difference test.

Increasing deficit irrigation caused a significant decrease in fresh fruit yield per plant. During the early period of harvesting, the highest fresh fruit yield reduction was $63.56 \%$ followed by $47.11 \%$ and $26.76 \%$ from $\mathrm{T} 4, \mathrm{~T} 3$, and $\mathrm{T} 2$ treatments, respectively, as compared with the control.

Fresh fruit yield at the middle and late periods showed a similar trend to the early period. Although the highest reduction in fresh fruit yield during the middle period of harvesting was $60.01 \%$ followed by $44.89 \%$ and $26.38 \%$, during the late period, it was found to be $66.29 \%$ followed by $48.01 \%$ and $28.11 \%$ from $\mathrm{T} 4, \mathrm{~T} 3$, and $\mathrm{T} 2$ treatments, respectively, as compared with the control.

Total fruit yield was decreased by increasing deficit irrigation as illustrated in Table 4. The highest total fruit yield was obtained from $\mathrm{T} 1$ followed by $\mathrm{T} 2, \mathrm{~T} 3$, and $\mathrm{T} 4$ treatments in descending order.

Reduction in yield, saving water, and irrigation water use efficiency. Reduction in total yield and amount of water saving resulting from deficit irrigation is presented in Table 5. Increasing deficit irrigation led to a severe yield reduction and a corresponding reduction in the amount of irrigation water.

Irrigating hot pepper at $85 \%$ of the WHC during the whole growing season reduced the total yield by $26.93 \%$ and saved $\approx 28.50 \%$ of the irrigation water. Meanwhile, irrigation at $70 \%$ and $55 \%$ of the WHC reduced the total yield by $46.55 \%$ and $63.30 \%$, respectively, and saved $\approx 51.72 \%$ and $67.69 \%$ of the irrigation water, respectively.

Irrigation water use efficiency in this study was unaffected by deficit irrigation. Table 5 illustrates that increasing deficit irrigation resulted in a nonsignificant increase in irrigation water use efficiency. The maximum increase was $13.39 \%$ followed by $10.47 \%$ and $2.01 \%$ from $\mathrm{T} 4, \mathrm{~T} 3$, and $\mathrm{T} 2$ treatments, respectively, relative to the control.

Table 3. Effect of deficit irrigation on fruit parameters of hot pepper during periods of harvesting.

\begin{tabular}{|c|c|c|c|c|c|}
\hline \multirow[b]{2}{*}{ Periods of harvesting } & \multirow[b]{2}{*}{ WHC $(\%)^{2}$} & \multicolumn{4}{|c|}{ Fruit parameters } \\
\hline & & Avg of fruit number & Avg of fruit length $(\mathrm{cm})$ & Avg of fruit diam $(\mathrm{cm})$ & Avg of fruit wt (g) \\
\hline & $\mathrm{T} 2^{\mathrm{x}}$ & $5.00 \pm 0.67 \mathrm{ab}$ & $13.71 \pm 0.07 b$ & $2.66 \pm 0.10 \mathrm{~b}$ & $33.72 \pm 0.86 b$ \\
\hline & $\mathrm{T} 3^{\mathrm{w}}$ & $4.44 \pm 0.19 b c$ & $13.32 \pm 0.16 b$ & $2.49 \pm 0.06 \mathrm{c}$ & $27.32 \pm 1.29 \mathrm{c}$ \\
\hline \multirow[t]{2}{*}{ Middle period } & $\mathrm{T} 1$ & $5.22 \pm 0.19 a$ & $14.76 \pm 0.50 \mathrm{a}$ & $2.91 \pm 0.02 \mathrm{a}$ & $34.63 \pm 1.72 \mathrm{a}$ \\
\hline & $\mathrm{T} 2$ & $4.77 \pm 0.20 \mathrm{~b}$ & $13.34 \pm 0.48 b$ & $2.45 \pm 0.10 \mathrm{~b}$ & $27.85 \pm 0.72 b$ \\
\hline \multirow[t]{4}{*}{ Late period } & $\mathrm{T} 1$ & $4.55 \pm 0.51 \mathrm{a}$ & $12.39 \pm 0.16 \mathrm{a}$ & $2.50 \pm 0.07 \mathrm{a}$ & $25.71 \pm 1.80 \mathrm{a}$ \\
\hline & $\mathrm{T} 2$ & $4.33 \pm 0.67 \mathrm{a}$ & $10.84 \pm 0.59 \mathrm{~b}$ & $2.25 \pm 0.02 b$ & $19.56 \pm 0.57 b$ \\
\hline & T3 & $3.89 \pm 0.51 \mathrm{a}$ & $10.30 \pm 0.75 b c$ & $2.10 \pm 0.05 \mathrm{c}$ & $15.70 \pm 0.41 \mathrm{c}$ \\
\hline & $\mathrm{T} 4$ & $3.66 \pm 0.88 \mathrm{a}$ & $9.48 \pm 0.37 \mathrm{c}$ & $1.90 \pm 0.05 \mathrm{~d}$ & $10.79 \pm 0.19 \mathrm{~d}$ \\
\hline
\end{tabular}

${ }^{\mathrm{z}}$ Water-holding capacity.

${ }^{\mathrm{y}}$ One hundred percent of water-holding capacity (control).

${ }^{x}$ Eighty-five percent of water-holding capacity.

${ }^{\text {w}}$ Seventy percent of water-holding capacity.

"Fifty-five percent of water-holding capacity.

"Data are mean \pm SD $(n=3)$.

${ }^{t}$ Values followed by the same letters within a column in each period are not significantly different $(P<0.05)$ according to the least significant difference test. 
Table 4. Effect of deficit irrigation on fresh fruit yield and total yield of hot pepper plant.

\begin{tabular}{|c|c|c|c|c|}
\hline \multirow[b]{2}{*}{ WHC $(\%)^{z}$} & \multicolumn{3}{|c|}{ Fresh fruit yield $(\mathrm{g}) /$ plant } & \multirow[b]{2}{*}{ Total fruit yield $(\mathrm{g})$} \\
\hline & Early period of harvesting & Middle period of harvesting & Late period of harvesting & \\
\hline $\mathrm{T} 1^{\mathrm{y}}$ & $229.61 \pm 29.24^{\mathrm{u}} \mathrm{a}^{\mathrm{t}}$ & $180.64 \pm 6.69 \mathrm{a}$ & $117.62 \pm 20.85 \mathrm{a}$ & $527.87 \pm 51.91 \mathrm{a}$ \\
\hline $\mathrm{T} 2^{\mathrm{x}}$ & $168.16 \pm 18.76 b$ & $132.98 \pm 7.26 b$ & $84.55 \pm 11.86 b$ & $385.69 \pm 34.73 b$ \\
\hline $\mathrm{T} 3^{\mathrm{w}}$ & $121.43 \pm 10.12 \mathrm{c}$ & $99.54 \pm 4.29 \mathrm{c}$ & $61.15 \pm 9.39 b c$ & $282.12 \pm 10.02 \mathrm{c}$ \\
\hline $\mathrm{T} 4^{\mathrm{v}}$ & $83.66 \pm 13.25 \mathrm{~d}$ & $70.43 \pm 6.38 \mathrm{~d}$ & $39.64 \pm 10.14 \mathrm{c}$ & $193.72 \pm 11.79 \mathrm{~d}$ \\
\hline
\end{tabular}

${ }^{\mathrm{z} W a t e r-h o l d i n g ~ c a p a c i t y . ~}$

${ }^{\mathrm{y}}$ One hundred percent of water-holding capacity (control).

${ }^{x}$ Eighty-five percent of water-holding capacity.

"Seventy percent of water-holding capacity.

${ }^{\vee}$ Fifty-five percent of water-holding capacity.

uData are mean \pm SD $(n=3)$.

${ }^{t}$ Values followed by the same letters within a column are not significantly different $(P<0.05)$ according to the least significant difference test.

Table 5. Effect of deficit irrigation on reduction in yield, saving water, and irrigation water use efficiency of hot pepper plant.

\begin{tabular}{|c|c|c|c|c|}
\hline WHC $(\%)^{z}$ & Total water applied (L/plant) & Saving water $(\%)$ & Reduction in yield (\%) & Irrigation water use efficiency $\left(\mathrm{g} \cdot \mathrm{L}^{-1}\right)$ \\
\hline $\mathrm{T} 1^{\mathrm{y}}$ & $29.62^{\mathrm{u}} \mathrm{a}^{\mathrm{t}}$ & 0.00 & 0.00 & $17.85 \mathrm{a}$ \\
\hline $\mathrm{T} 2^{\mathrm{x}}$ & $21.18 \mathrm{~b}$ & 28.50 & 26.93 & $18.21 \mathrm{a}$ \\
\hline $\mathrm{T} 3^{\mathrm{w}}$ & $14.30 \mathrm{c}$ & 51.72 & 46.55 & $19.72 \mathrm{a}$ \\
\hline $\mathrm{T} 4^{\mathrm{v}}$ & $9.57 \mathrm{~d}$ & 67.69 & 63.30 & $20.24 \mathrm{a}$ \\
\hline
\end{tabular}

${ }^{\mathrm{z}}$ Water-holding capacity.

${ }^{y}$ One hundred percent of water-holding capacity (control).

${ }^{x}$ Eighty-five percent of water-holding capacity.

weventy percent of water-holding capacity.

${ }^{v}$ Fifty-five percent of water-holding capacity.

uData are mean \pm SD $(\mathrm{n}=3)$.

${ }^{t}$ Values followed by the same letters within a column are not significantly different $(P<0.05)$ according to the least significant difference test.

Root characteristics. The effect of deficit irrigation treatments on length and fresh and dry weights of roots and root-to-shoot ratio is shown in Table 6. This experiment demonstrated that length and fresh weight of roots were significantly reduced by the increase in deficit irrigation. The highest reduction in root length was $20.89 \%$ followed by $15.32 \%$ and $7.43 \%$, whereas the maximum reduction in fresh weight was $39.88 \%$ followed by $23.29 \%$ and $13.71 \%$ in $\mathrm{T} 4, \mathrm{~T} 3$, and $\mathrm{T} 2$ treatments, respectively, as compared with the control.

A significant decrease in dry weight of roots was obtained as a result of increased deficit irrigation (Table 6). A nonsignificant increase in root-to-shoot ratio was noticed as deficit irrigation was increased. T4 treatment exhibited the maximum reduction in dry weight of roots $(28.24 \%$, relative to the control) and the highest increase in root-toshoot ratio ( $11.59 \%$, relative to the control).

Vitamin C content. Data illustrated in Figure 2 showed a continued significant increase in fruit content of vitamin $\mathrm{C}$ until it reached the peak at $30 \mathrm{~d}$ after flowering. Afterward, vitamin $\mathrm{C}$ content tended to decline at $40 \mathrm{~d}$ after flowering and continued to decline significantly thereafter until $60 \mathrm{~d}$ from flowering.

Generally, the results have confirmed that vitamin $\mathrm{C}$ content of pepper fruits was decreased significantly by increasing deficit irrigation. As a result, the highest average vitamin $\mathrm{C}$ content value $[91.43 \mathrm{mg} / 100 \mathrm{~g}$ fresh weight $(\mathrm{FW})]$ was obtained from $\mathrm{T} 1$ treatments at $30 \mathrm{~d}$ after flowering followed by $87.38,73.91$ and $66.70 \mathrm{mg} / 100 \mathrm{~g} \mathrm{FW}$ from $\mathrm{T} 2, \mathrm{~T} 3$, and $\mathrm{T} 4$, respectively, at $30 \mathrm{~d}$ after flowering. However, there were no significant differences in vitamin $\mathrm{C}$ content between $\mathrm{T} 1$ and $\mathrm{T} 2$ treatment samples collected $30 \mathrm{~d}$ after flowering.

\section{Discussion}

Deficit irrigation is considered an important abiotic stress factor affecting plant growth parameters and yield. It influences plant growth at various levels from the cell to the community (Blumwald et al., 2004; Colom and Vazzana, 2001). The quantity and quality of plant growth depend on cell division, enlargement, differentiation, and all of these events are affected by water stress (Cabuslay et al., 2002; Correia et al., 2001).

Our results indicated that deficit irrigation had a considerable effect on plant growth parameters, fruit, and yield of pepper. As a result of increased deficit irrigation, plant height, stem diameter, number of branches, leaf area, and fresh and dry weights of shoots were reduced. This reduction could be attributed to a reduction in leaf cell expansion and possibly by a lower rate of cell division in the plant (Sayyari and Ghanbari, 2012; Tadesse, 1997). Furthermore, water reduction leads to the reduction of sunlight absorption and photosynthesis level of the plant resulting from reducing leaf area, which leads to the reduction in the dry matter and plant yield production (Hong-Bo et al., 2008). Our results are also in agreement with the findings of Abayomi et al. (2012) who found that plant growth parameters of plant height, number and area of leaves per plant, and number of flowers per plant were significantly decreased by low soil moisture content.

Results, with respect to the response of plant height to water deficit, in our experiment were in agreement with the findings reported by Techawongstein et al. (1992) who demonstrated the suppression of plant height as a result of water stress in chili. Beese et al. (1982) have also reported the reduction in above-ground plant parts in chili as a result of the effect of moisture stress. Similarly, many researchers such as Hedge (1989), Jaleel et al. (2008), Khan et al. (2008), and Smittle et al. (1994) have found lower values of different plant parts as a result of water stress.

Under these experimental conditions, fruits grown under deficit irrigation were harvested earlier than well-watered ones. This early fruit harvesting is believed to be the result of an increase in stored carbohydrates (Dekoning and Hurd, 1983). Moreover, the decrease in vegetative growth and flower bud initiation resulting from low turgor might hasten reproductive maturity by decreasing competition for carbohydrate (Sylvertesn, 1985). The same results were also demonstrated by Tadesse (1997).

Our experiment identified a strong relationship between the vegetative and fruit parameters. Full irrigation improved vegetative growth parameters, which in turn led to an increase in number of fruit, yield, and total yield. On the other hand, a significant decrease in net photosynthesis rate and chlorophyll content of a leaf was observed by increasing deficit irrigation (data not shown). This reduction in net photosynthesis rate and chlorophyll content started slightly 30 to $45 \mathrm{~d}$ after transplanting and declined sharply afterward. This could be an explanation for the reduction in fruit parameters at middle and late periods of harvesting followed by a reduction in total yield, as was hypothesized by Hong-Bo et al. (2008).

Likewise, Abayomi et al. (2012) have demonstrated that number and weights of marketable fruits of pepper were decreased by low soil moisture. Ismail (2010) has also indicated that deficit irrigation decreased 
Table 6. Effect of deficit irrigation on root characteristics and root-to-shoot ratio of hot pepper plant.

\begin{tabular}{lcccc}
\hline WHC $(\%)^{\mathrm{z}}$ & Root length $(\mathrm{cm})$ & Fresh wt of root $(\mathrm{g})$ & Dry wt of root $(\mathrm{g})$ & Root/shoot ratio \\
T1 $^{\mathrm{y}}$ & $39.30 \pm 2.61^{\mathrm{u}} \mathrm{a}^{\mathrm{t}}$ & $55.34 \pm 9.15 \mathrm{a}$ & $17.42 \pm 3.11 \mathrm{a}$ & $0.276 \pm 0.052 \mathrm{a}$ \\
T2 $^{\mathrm{x}}$ & $36.38 \pm 1.34 \mathrm{ab}$ & $47.75 \pm 5.96 \mathrm{ab}$ & $15.12 \pm 1.60 \mathrm{ab}$ & $0.280 \pm 0.020 \mathrm{a}$ \\
T3 $^{\mathrm{w}}$ & $33.28 \pm 2.06 \mathrm{bc}$ & $42.45 \pm 3.91 \mathrm{bc}$ & $13.94 \pm 2.52 \mathrm{ab}$ & $0.282 \pm 0.031 \mathrm{a}$ \\
T4 $^{\mathrm{v}}$ & $31.09 \pm 1.02 \mathrm{c}$ & $33.27 \pm 2.20 \mathrm{c}$ & $12.50 \pm 0.81 \mathrm{~b}$ & $0.308 \pm 0.033 \mathrm{a}$ \\
\hline
\end{tabular}

${ }^{\mathrm{z}}$ Water-holding capacity.

${ }^{y}$ One hundred percent of water-holding capacity (control).

${ }^{x}$ Eighty-five percent of water-holding capacity.

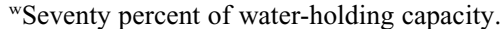

${ }^{\vee}$ Fifty-five percent of water-holding capacity.

"Data are mean \pm SD $(n=3)$.

${ }^{t}$ Values followed by the same letters within a column are not significantly different $(P<0.05)$ according to the least significant difference test.

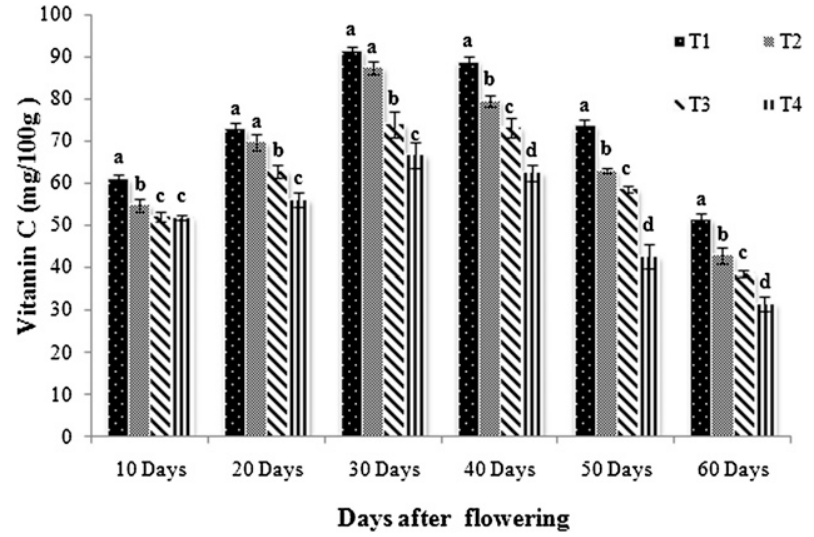

Fig. 2. Effect of deficit irrigation on fruit content of vitamin $\mathrm{C}$ during different times (days after flowering) of hot pepper. $\mathrm{T} 1=100 \%$ of water-holding capacity (control); $\mathrm{T} 2=85 \%$ of water-holding capacity; $\mathrm{T} 3=70 \%$ of water-holding capacity; $\mathrm{T} 4=55 \%$ of water-holding capacity. Vertical bars denote the SD. Columns in figure that are headed with the same letter in each group separately are not significantly different $(P<0.05)$ according to the least significant difference test.

fresh fruit yield of bird pepper. In this study, different levels of deficit irrigation were observed to decrease total yield. These results are in a similar pattern with those of Khan et al. (2008). They obtained a significantly reduced number of fruits per plant, individual fruit weight, and dry weight per plant from a water-stressed pepper plant. In addition, Gencoglan et al. (2006) have also reported a significant effect of deficit irrigation on fruit number, fruit dry weight, and dry yield of hot pepper. They found that the average fruit number of non-stressed hot pepper plant plants increased three times compared with water-stressed ones. These results were also further supported by Kirda et al. (2007) who have observed a yield reduction from 37.4 to $20.3 \mathrm{t} \cdot \mathrm{ha}^{-1}$ when irrigation was reduced from 344 to $173 \mathrm{~mm}$ in pepper. Dorji et al. (2005) reported that total fruit number per plant and total FW of fruit were reduced by more than $20 \%$ and $37 \%$ in deficit irrigation, respectively, compared with the control. Similarly, our results are in agreement with the findings of Antony and Singandhupe (2004), Cantore et al. (2000), Delfine et al. (2000), Della Costa and Gianquinto (2002), Rezende et al. (2003), and Techawongstein et al. (1992).

Our results indicate that deficit irrigation caused a reduction in root parameters like root length and fresh and dry weights of roots. This reduction could be attributed to the reduction of turgor pressure as reported in wheat
(Ali Dib and Monneveux, 1992; Benlaribi et al., 1990). Similar results were obtained by Sacks et al. (1997) who demonstrated that the root growth was not significantly reduced under water deficits in maize and wheat. Furthermore, water stress reduced the fibrous roots biomass in avocado cultivars (Nicholas, 1998) and in pearl millet (Lawlor and Cornic, 2002; Manivannan et al., 2007a). The dry weight of root was also decreased under mild and severe water stress conditions in Populus species (Wullschleger et al., 2005).

The increase in root-to-shoot ratio under water stress conditions is to facilitate water absorption (Nicholas, 1998) and it is related to abscisic acid content of roots and shoots (Manivannan et al., 2007b; Sharp and LeNoble, 2002). The ratio values of root to shoot are narrow, because the decrease in root weight corresponded with a reduction change in shoot weight.

Our results demonstrated a strong relationship between vitamin $\mathrm{C}$ content and ripening stage of the fruit. Vitamin $\mathrm{C}$ content was observed to rise slightly at 10 and $20 \mathrm{~d}$ after flowering, until it reached its highest value at the ripening stage $(30 \mathrm{~d}$ after flowering). Afterward, vitamin $\mathrm{C}$ content declined at 40 and $50 \mathrm{~d}$ after flowering and reached the lowest valued $60 \mathrm{~d}$ after flowering. Its increase at the beginning of ripening and decrease with advanced ripening were attributed to its consumption by the plant as a result of the antioxidant role of ascorbic acid, which increases with the increasing respiration rate in climacteric fruits (Howard et al., 1994, 2000; Márkus et al., 1999; Navarro et al., 2006; Osuna-Garcia et al., 1998).

Furthermore, our results were also in agreement with the findings of Mahendran and Bandara (2000) and Vijitha and Mahendran (2010) illustrating that deficit irrigation has been found to cause a significant decrease in vitamin $C$ content. As the route for vitamin C synthesis commences from D-glucose (Counsel and Horning, 1981), the reduction in vitamin $\mathrm{C}$ content might be attributed to the reduction in the D-glucose synthesis level, which would have occurred during the period of stress, which in turn may have reduced the synthesis of vitamin $\mathrm{C}$. This is maybe because moisture stress could have reduced the substrate concentration for vitamin $\mathrm{C}$ synthesis. The noticeable reduction in the substrate may possibly also be the result of reduced photosynthetic rate.

Because of the fact that vitamin $\mathrm{C}$ is very sensitive to changes in environmental conditions and it gets oxidized very rapidly when exposed to high temperatures (Davies et al., 1991), a possible reduction in vitamin $C$ content may be the result of increased leaf temperature, which may be also the result of lowered transpirational cooling with the onset of stress. Generally, leaf temperature progressively builds up as a consequence of moisture stress and contributes toward the reduction of vitamin $\mathrm{C}$ (Mahendran and Bandara, 2000).

As a matter of fact, decreased water supply to pepper plants led to more water savings. However, irrigation water use efficiency was nonsignificantly increased. This increment in irrigation water use efficiency could be explained by findings of Dorji et al. (2005); they found that total dry mass of pepper fruit per plant under deficit irrigation was similar to a non-deficit. This indicates that water movement into the fruit may have decreased with progressive development of water deficit without affecting the translocation of dry matter into the fruit. This result led to an increase in mass production per unit of water, which led to an increase in irrigation water use efficiency (Ismail, 2010). The values of irrigation water use efficiency were closer because of the reason that decreased water supply corresponds with a high reduction in yield. 


\section{Conclusion}

Our results showed that hot pepper cultivar Battle is a water stress-sensitive plant. Increased deficit irrigation has decreased vegetative growth and fruit parameters. Moreover, vitamin $\mathrm{C}$ content was decreased as deficit irrigation was increased. The highest value of vitamin $C$ content was obtained at the ripening stage as a result of $100 \%$ or $85 \%$ of WHC treatments, which showed nonsignificant differences. Using $85 \%$ of WHC for this cultivar could be a critical deficit irrigation level for a high content of vitamin $\mathrm{C}$ and saving a high amount of irrigation water, which outweighs the reduction in total fresh fruit yield.

\section{Literature Cited}

Abayomi, Y.A., M.O. Aduloju, M.A. Egbewunmi, and B.O. Suleiman. 2012. Effects of soil moisture contents and rates of NPK fertilizer application on growth and fruit yields of pepper (Capsicum spp.) genotypes. Intl. J. Agr. Sci. 2:651-663.

Abebe, Y.A. 2009. Managing the soil water balance of hot pepper (capsicum annuum L.) to improve water productivity. $\mathrm{PhD}$ thesis, Pretoria University, Pretoria, South Africa.

Ali Dib, T. and P. Monneveux. 1992. Adaptation à la sécheresse et notion d'idéotype chez le blé dur. I. Caractères morphologiques d'enracinement. Agronomie 12:371-379.

Alvino, A., M. Centritto, and F. De Lorenzi. 1994. Phytosynthesis response of sunlit and shade pepper leaves at different positions in the canopy under two water regimes. Austral. J. Plant Physiol. 21:377-391.

Antony, E. and R.B. Singandhupe. 2004. Impact of drip and surface irrigation on growth, yield and WUE of capsicum (Capsicum annuum L.). Agr. Water Mgt. 65:121-132.

AOAC. 1998. Official methods of analysis. 15th Ed. New York, NY. p. 8-14.

Beese, F., R. Horton, and P.J. Wierenga. 1982. Growth and yield response of chilli pepper to trickle irrigation. Agron. J. 74:556-561.

Benlaribi, M., P. Monneveux, and P. Grignac. 1990. Etude des caractères d'enracinement et de leur rôle dans l'adaptation au déficit hydrique chez le blé dur (Triticum durum Desf.). Agronomie 10:305-322.

Blumwald, E., G. Anil, and G. Allen. 2004. New directions for a diverse planet. Proc. 4th Int. Crop Science Congr., 26 Sept. to 1 Oct., Brisbane, Australia (CD-ROM) $<$ http://www. cropscience.org.au>

Cabuslay, G.S., O. Ito, and A.A. Alejal. 2002 Physiological evaluation of responses of rice (Oryza sativa L.) to water deficit. Plant Sci. 63:815-827.

Cantore, V., F. Boari, and A. Caliandro. 2000. Effect of split-root-system water stress on physiological and morphological aspects of pepper (Capsicum annuит L.). Acta Hort. 537:321-328.

Chartzoulakis, K. and N. Drosos. 1997. Water requirements of glasshouse grown pepper under drip irrigation. Acta Hort. 499:175-180.

Colom, M.R. and C. Vazzana. 2001. Drought stress effects on three cultivars of Eragrostis curvula: Photosynthesis and water relations. Plant Growth Regulat. 34:195-202.

Correia, M.J., D. Coelho, and M.M. David. 2001. Response to seasonal drought in three cultivars of Ceratonia siliqua; leaf growth and water relation. Tree Physiol. 21:645-653.
Counsel, J.N. and D.H. Horning. 1981. Vitamin C and ascorbic acid. Appl. Sci., Cambridge, UK.

Dagdelen, N., E. Yilmaz, F. Sezgin, and T. Gurbuz. 2004. Effect of water stress at different growth stages on processing pepper (Capsicum annum cv. Kapijia) yield water use and quality characteristics. Pak. J. Biol. Sci. 7:2167-2172.

Davies, M.B., J. Austin, and D.A. Partridge. 1991. Vitamin C; its chemistry and biochemistry. The Royal Society of Chemistry, Cambridge, UK.

Dekoning, A. and R.G. Hurd. 1983. A comparison of winter tomato plants growth with restricted and unlimited water supply. J. Hort. Sci. 58 : 575-581.

Delfine, S., A. Alvino, F. Loreto, M. Centrito, and G. Santarelli. 2000. Effects of water stress on the yield and photosynthesis of field-grown sweet pepper (Capsicum annum L.). Acta Hort. 537:223-229.

Della Costa, L. and G. Gianquinto. 2002. Water stress and water-table depth influence yield, water use efficiency, and nitrogen recovery in bell pepper: Lysimeter studies. Austral. J. Agr. Res. 53:201-210.

Dimitrov, Z. and A. Ovtcharrova. 1995. The productivity of peppers and tomatoes in case of insufficient water supply. Proc. of ICID Specia Technical Session on the Role of Advanced Technologies in Irrigation and Drainage System. Vol. 1ft9.1-ft9.5.

Dorji, K., M.H. Behboudian, and J.A. ZegbeDominguez. 2005. Water relations, growth, yield, and fruit quality of hot pepper under deficit irrigation and partial root zone drying. Sci. Hort. 104:137-149.

English, M.J. and S.N. Raja. 1996. Perspective of deficit irrigation. Agr. Water Mgt. 32:1-14.

Ferrara, A., S. Lovelli, T. Di Tommaso, and M. Perniola. 2011. Flowering, growth and fruit setting in greenhouse bell pepper under water stress. J. Agron. 10:12-19.

Gencoglan, C., I.E. Akinci, K. Ucan, S. Akinci, and S. Gencoglan. 2006. Response of red hot pepper plants (Capsicum annuum L.) to the deficit irrigation. Akdeniz Univ. Ziraat Fak. Derg. 19:131-138.

Gnayfeed, M.H., H.G. Daood, P.A. Biacs, and C.F. Alcaraz. 2001. Content of bioactive compounds in pungent spice red pepper (paprika) as affected by ripening and genotype. J. Sci. Food Agr. 81:1580-1585.

Guang-Cheng, S., Z. Zhan-Yu, L. Na, Y. ShuangEn, and X. Weng-Gang. 2008. Comparative effects of deficit irrigation (DI) and partial rootzone drying (PRD) on soil water distribution, water use, growth and yield in greenhouse grown hot pepper. Sci. Hort. 119:11-16.

Harris, J.R. 1996. Subcellular biochemistry, ascorbic acid: Biochemistry and biomedical cell biology. Vol. 25. Plenum Press, New York, NY. p. 215-231

Hedge, D.M. 1989. Effects of soil moisture and nitrogen on plant water relations, minera composition and productivity of bell pepper (Capsicum annum). Indian J. Agron. 34:30-34

Hong-Bo, S., C. Li-Ye, A.j. Cheruth, and Z. ChangXing. 2008. Water deficit stress induced anatomical changes in higher plants. Current Res. Biol. 331:215-225.

Howard, L.R., R.T. Smith, A.B. Wagner, B. Villalon, and E.E. Burns. 1994. Provitamin A and ascorbic acid content of fresh pepper cultivars (Capsicum annuum) and processed jalapenos. J. Food Sci. 59:362-365.

Howard, L.R., S.T. Talcott, C.H. Brenes, and B. Villalon. 2000. Changes in phytochemical and antioxidant activity of selected pepper cultivars
(Capsicum species) as influenced by maturity J. Agr. Food Chem. 48:1713-1720.

Ismail, S.M. 2010. Influence of deficit irrigation on water use efficiency and bird pepper production (Capsicum annuum L.). JKAU: Met. Environ. and Arid Land Agr. Sci. 21:29-43.

Jaleel, C.A., R. Gopi, B. Sankar, M. Gomathinayagam, and R. Panneerselvam. 2008. Differential responses in water use efficiency in two varieties of Catharanthus roseus under drought stress. Current Res. Biol. 331:42-47.

Khan, M.A.I., A.M. Farooque, M.A. Haque, M.A Rahim, and M.A. Hoques. 2008. Effects of water stress at various growth stages on the physio-morphological characters and yield in chili. Bangladesh J. Agr. Res. 33:353-362.

Kirda, C., S. Topcu, M. Cetin, H.Y. Dasgan, H. Kaman, F. Topaloglu, M.R. Derici, and B. Ekici. 2007. Prospects of partial root zone irrigation for increasing irrigation water use efficiency of major crops in the Mediterranean region. Ann. Appl. Biol. 150:281-291.

Kulkarni, M. and S. Phalke. 2009. Evaluating variability of root size system and its constitutive traits in hot pepper (Capsicum annum $\mathrm{L}$.) under water stress. Sci. Hort. 120:159-166.

Lawlor, D.W. and G. Cornic. 2002. Photosynthetic carbon assimilation and associated metabolism in relation to water deficits in higher plants. Plant Cell Environ. 25:275-294.

Márkus, F., H.G. Daood, J. Kapitany, and P.A Biacs. 1999. Change in the carotenoid and antioxidant content of spice red pepper (paprika) as a function of ripening and some technological factors. J. Agr. Food Chem. 47:100-107.

Mahendran, S. and D.C. Bandara. 2000. Effects of soil moisture stress at different growth stages on vitamin $\mathrm{C}$, capsaicin, and $\beta$-carotene contents of chili (Capsicum annum L.) fruits and their impact on yield. Trop. Agr. Res. 12:95-106.

Manivannan, P., C.A. Jaleel, A. Kishorekumar, B. Sankar, R. Somasundaram, R. Sridharan, and R. Panneerselvam. 2007a. Drought stress induced changes in the biochemical parameters and photosynthetic pigments of cotton (Gossypium hirsutum L.). Indian J. Appl. Pure Biol. 52:369-372.

Manivannan, P., C.A. Jaleel, B. Sankar, A. Kishorekumar, R. Somasundaram, A.G.M Lakshmanan, and R. Panneerselvam. 2007b. Growth, biochemical modifications and proline metabolism in Helianthus annuus L. as induced by drought stress. Colloids Surf. B Biointerfaces 59:141-149.

Marín, A., F. Ferreres, F.A. Tomas-Barberan, and M.I. Gil. 2004. Characterization and quantitation of antioxidant constituents of sweet pepper (Capsicum annuum L). J. Agr. Food Chem. 52:3861-3869.

Marín, A., J.S. Rubio, V. Mart'nez, and M.I. Gil. 2009. Antioxidant compounds in green and red peppers as affected by irrigation frequency, salinity and nutrient solution composition. J. Sci. Food Agr. 89:1352-1359.

Namiki, M. 1990. Antioxidants/antimutagens in food. CRC Crit. Rev. Food Sci. Nutr. 29:273300

Navarro, J.M., P. Flores, C. Garrido, and V. Martinez. 2006. Changes in the contents of antioxidant compounds in pepper fruits at different ripening stages, as affected by salinity. Food Chem. 96:66-73.

Nicholas, S. 1998. Plant resistance to environmental stress. Curr. Opin. Biotechnol. 9:214-219.

Osuna-Garcia, J.A., M.M. Wall, and C.A. Waddell. 1998. Endogenous levels of tocopherols and ascorbic acid during fruit ripening of New 
Mexican-type chile (Capsicum annuum L.). J. Agr. Food Chem. 46:5093-5096.

Palevitch, D. and L.E. Craker. 1995. Nutritional and medicinal importance of red pepper (Capsicum spp.). J. Herbs Spices Med. Plants 3:55-83.

Rezende, F.C., J.A. Frizzone, R.F. Oliveiraand, and A.S. Pereira. 2003. $\mathrm{CO}_{2}$ and irrigation in relation to yield and water use of bell pepper crop. Scientia Agricola 60:7-12.

Ruiz-Lau, N., F. Medina-Lara, Y. Minero-García, E. Zamudio-Moreno, A. Guzma'n-Antonio, I. Echevarría-Machado, and M. MartínezEstévez. 2011. Water deficit affects the accumulation of capsaicinoids in fruits of Capsicum chinense Jacq. HortScience 46:487-492.

Sacks, M.M., W.K. Silk, and P. Burman. 1997. Effect of water stress on cortical cell division rates within the apical meristem of primary roots of maize. Plant Physiol. 114:519-527.

Sayyari, M. and F. Ghanbari. 2012. Effects of super absorbent polymer A200 on the growth, yield and some physiological responses in sweet pepper (Capsicum annuum L.) under various irrigation regimes. Intl. J. Agr. Food Res. 1:1-11.

Sharp, R.E. and M.E. LeNoble. 2002. ABA, ethylene and the control of shoot and root growth under water stress. J. Expt. Bot. 53:33-37.

Smittle, D.A., W.L. Dickens, and J.R. Stemsell. 1994. Irrigation regimes affect yield and water use by bell pepper. J. Amer. Soc. Hort. Sci. 119:936-939.

Sorensen, J.N., A.S. Hohansen, and K. Kaack. 1995. Marketable and nutritional quality of leeks as affected by water and nitrogen supply and plant age at harvest. J. Sci. Food Agr. 68:367-373.

Sylvertesn, J.P. 1985. Integration of water stress in fruit trees. HortScience 20:1039-1042.

Tadesse, T. 1997. Some factors affecting the yield and quality of sweet pepper (Capsicum annuum L. cv. Domino). PhD thesis, Massey University, New Zealand.
Techawongstein, S., E. Nawata, and S. Shigenga. 1992. Effect of water stress at various stages of plant development on growth and yield of chili pepper. Japan J. Trop. Agr. 36:51-57.

Toivonen, P.M.A., B.J. Zebarth, and P.A. Bowen. 1994. Effect of nitrogen fertilization on head size, vitamin $\mathrm{C}$ content and storage life of broccoli (Brassica oleracea var. italica). Can. J. Plant Sci. 74:607-610.

Vijitha, R. and S. Mahendran. 2010. Effect of moisture stress at different growth stages of tomato plant (Lycopersicon esculentum Mill.) on yield and quality of fruit. J. Sci. Univ. Kelaniya 5:1-11.

Wullschleger, S.D., T.M. Yin, S.P. DiFazio, T.J. Tschaplinski, L.E. Gunter, M.F. Davis, and G.A. Tuskan. 2005. Phenotypic variation in growth and biomass distribution for two advanced-generation pedigrees of hybrid poplar. Can. J. Res. 35:1779-1789. 